\title{
Acromegaly treatment in Romania. How close are we to disease control?
}

\author{
Leczenie akromegalii w Rumunii. Jak blisko jesteśmy uzyskania kontroli nad \\ chorobą?
}

\section{Dan Alexandru Niculescu', Ionela Florina Baciu', Cristina Capatina ${ }^{1}$, Simona Andreea Galoiu', Monica Livia Gheorghiu ${ }^{1}$, Serban Radian ${ }^{1}$, Raluca Alexandra Trifanescu ${ }^{1}$, Andra Caragheorgheopol' Mihail Coculescu ${ }^{1}$, Catalina Poiana ${ }^{1}$}

${ }^{1}$ Carol Davla University of Medicine and Pharmacy, Bucharest, Romania

${ }^{2}$ C. I. Parhon Institute of Endocrinology, Bucharest, Romania

\begin{abstract}
Introduction: In Romania, no nationwide data for acromegaly treatment and control rate are available. Our objective was to assess the acromegaly control rate in a tertiary referral centre, which covers an important part of Romanian territory and population of patients with acromegaly.

Materials and methods: We reviewed the records of all 164 patients (49 males and 115 females; median age 55 [47, 63.5] years) with newly or previously diagnosed acromegaly, who have been assessed at least once in our tertiary referral centre between January 1, 2012 and March 31, 2016. This sample represents $13.6 \%$ of the total expected 1200 Romanian patients with acromegaly and covers $82.9 \%$ of the counties in Romania. Control of acromegaly was defined as a random serum growth hormone $(\mathrm{GH})<1 \mathrm{ng} / \mathrm{mL}$ and an age-normalised serum insulin-like growth factor-I (IGF-I) value. The GH and IGF-I values used for calculation of the control rate were those at the last evaluation. The same assays for GH and IGF-I measurement were used in all patients.

Results: There were 147 treated and 17 untreated patients. Of the 147 patients assessed after therapy, $137(93.2 \%)$ had pituitary surgery, $116(78.9 \%)$ were on medical treatment at the last evaluation, and $67(45.5 \%)$ had radiotherapy. Seventy-one (48.3\%) had a random $\mathrm{GH}<1 \mathrm{ng} / \mathrm{mL}, 54(36.7 \%)$ had a normalised, age-adjusted IGF-I, and $42(28.6 \%)$ had both normal random serum GH and IGF-I.

Conclusions: In Romania, acromegaly benefits from the whole spectrum of therapeutic interventions. However, the control rate remains disappointing. (Endokrynol Pol 2017; 68 (5): 519-523)
\end{abstract}

Key words: acromegaly, Romania, treatment, control rate

\section{Streszczenie}

Wstęp: W Rumunii nie są dostępne ogólnokrajowe dane dotyczące leczenia akromegalii ani wskaźnika kontroli choroby. Badanie przeprowadzono w celu oceny wskaźnika kontroli akromegalii w ośrodku referencyjnym trzeciego stopnia, który obejmuje opieką zdrowotną znaczną część obszaru Rumunii i populacji pacjentów z akromegalią.

Materiał i metody: Autorzy dokonali przeglądu danych medycznych wszystkich 164 chorych [49 mężczyzn i 115 kobiet; mediana wieku 55 lat $(47 ; 63,5)$ ] z noworozpoznaną lub wcześniej zdiagnozowaną akromegalią, których przynajmniej jednokrotnie zbadano w ośrodku referencyjnym trzeciego stopnia (miejsce pracy autorów) w okresie od 1 stycznia 2012 roku do 31 marca 2016 roku. Ta próba stanowiła 13,6\% całej rumuńskiej populacji chorych na akromegalię szacowaną na 1200 osób i reprezentowała 82,9\% okręgów administracyjnych w Rumunii. Kontrolę akromegalii definiowano jako stężenie przygodne hormonu wzrostu (growth hormone, GH) w surowicy wynoszące poniżej $1 \mathrm{ng} / \mathrm{ml}$ oraz normalizacja odpowiednio do wieku stężenia insulinopodobnego czynnika wzrostu 1 (insulin-like growth factor-1, IGF-1) w surowicy. Do obliczenia wskaźnika kontroli choroby stosowano wartości GH i IGF-1 z ostatnich pomiarów. U wszystkich pacjentów używano tych samych testów do pomiarów GH i IGF-1.

Wyniki: Badanie obejmowało 147 chorych poddanych leczeniu i 17 chorych nieleczonych. Spośród 147 chorych ocenianych po terapii, u $137(93,2 \%)$ zastosowano leczenie chirurgiczne, $116(78,9 \%)$ w momencie ostatniej wizyty kontrolnej stosowało leczenie farmakologiczne, a $67(45,5 \%)$ poddano radioterapii. U 71 chorych $(48,3 \%)$ przygodne stężenie $\mathrm{GH}$ w surowicy wynosiło poniżej $1 \mathrm{ng} / \mathrm{ml}, \mathrm{u} 54$ (36,7\%) uzyskano normalizację stężenia IGF-1 skorygowanego względem wieku, a u 42 chorych $(28,6 \%)$ uzyskano normalizację obu parametrów —-GH i IGF-1. Wnioski: W Rumunii u chorych na akromegalię stosuje się szerokie spektrum interwencji terapeutycznych, jednak wskaźnik kontroli choroby nadal pozostaje niezadawalający. (Endokrynol Pol 2017; 68 (5): 519-523)

Słowa kluczowe: akromegalia, Rumunia, leczenie, wskaźnik kontroli choroby

\section{Introduction}

Uncontrolled acromegaly is a well-known cause of increased morbidity and mortality [1]. Recent decades have brought an improvement in acromegaly control, but, depending on the criteria used, it does not exceed $68-95 \%$ of patients after surgery [2] or $75-90 \%$ of patients on medical treatment with somatostatin ana- 
logues (SSA) [3] or pegvisomant [4]. Moreover, there is an important heterogeneity in acromegaly control rates between centres [5-7] or between industry-sponsored clinical trials and real-life studies [4, 8]. In addition, a significant number of patients need a multimodal treatment approach including surgery, various medical therapies, and radiotherapy. These patients are rarely involved in randomised clinical trials.

The best tool to measure nationwide success in the treatment of acromegaly is a country-specific database or register covering as many patients as possible over a long period of time. At present, multiple country databases are functional throughout Europe [5-7, 9, 10]. Unfortunately, Romania does not have such a register, and no nationwide data for acromegaly treatment and control rate are available.

Our objective was to assess the acromegaly control rate in a tertiary referral centre, which covers an important part of Romanian territory and population of patients with acromegaly.

\section{Materials and Methods}

\section{Subjects}

Starting on January 1, 2012 the "C. I. Parhon" Institute of Endocrinology constantly used the same assays for serum growth hormone $(\mathrm{GH})$ and insulin-like growth factor-I (IGF-I) measurement, according to the Endocrine Society Guidelines for Acromegaly [11]. Hence, we reviewed the charts of all patients with confirmed acromegaly, who were assessed at least once in our tertiary referral centre between January 1, 2012 and March 31, 2016. During this period we assessed 164 patients with newly or previously diagnosed acromegaly from 34 counties. There were 49 males and 115 females, with a median age of $55(47,63.5)$ years. As the prevalence of acromegaly is considered to be around 60 cases per million [12] for an estimated Romanian population of 20 million, our centre assessed $13.6 \%$ of the total expected 1200 Romanian patients with acromegaly. Our population covered 34 of the 41 Romanian counties (Bucharest and Ilfov county taken together), i.e. $82.9 \%$ (Fig. 1A).

Of the total 164 patients, $57(34.7 \%)$ had newly diagnosed acromegaly. There were 15 males and 42 females with a median age of $55(43.7,60.5)$ years. At an estimated incidence of 3-4 cases per million [10, 12] due in the majority of cases to a $\mathrm{GH}$-secreting pituitary adenoma, and occurring with a population prevalence of 60 per million and an incidence of 3-4 per million per year. Males and females appear to be equally affected with an average age of presentation of 44 years. Younger patients may have more aggressive tumours and higher GH concentrations. There is co-existent hyperprolactinaemia in about one third of cases, and a variable proportion of [figure: see text] tumours appear to have activating mutations of the gsp gene or other genetic abnormalities. Acute complications such as carpal tunnel syndrome, sweating and obstructive sleep apnoea are usually readily reversible with treatment of the condition, but chronic complications such as hypertension, diabetes and heart disease are less readily corrected and post-treatment GH levels of $<2.5 \mathrm{ug} / \mathrm{L}$ (5 mU/L per year, Romania should have $60-80$ new cases of acromegaly per year. The estimated incidence for the 51 months of the study is 13.4 new cases of acromegaly per year, 16.7-22.3\% of the estimated Romanian patient population. This population covered 20 counties, $48.7 \%$ of Romanian territory (Fig. 1B).

\section{Assays}

Control of acromegaly was defined according to Endocrine Society guidelines [11]: a random serum $\mathrm{GH}<$ $1 \mathrm{ng} / \mathrm{mL}$ and an age-normalised serum IGF-I value. The GH and IGF-I values used for calculation of the control rate were those at the last evaluation.

Serum GH was measured using a chemiluminescence assay (Liaison, Sallugia, Italy). The assay is referenced to WHO Second International Standard 98/574 for somatropin (22-kDa recombinant DNA-derived materials). The functional sensitivity is $0.05 \mathrm{ng} / \mathrm{mL}$, and the analytical sensitivity is $0,009 \mathrm{ng} / \mathrm{mL}$.

Serum IGF-I was measured using a Liaison IGF-I chemiluminescence assay (DiaSorin, Sallugia, Italy). The assay is referenced to the 02/254 International Standard for Insulin-like Growth Factor-I NIBSC. The assay functional sensitivity is $15 \mathrm{ng} / \mathrm{mL}$, and the analytical sensitivity is $3 \mathrm{ng} / \mathrm{mL}$.

\section{Statistics}

Data are presented as number (percentage) or median $\left(25^{\text {th }}, 75^{\text {th }}\right.$ percentile). Wilcoxon test was used to test differences between paired groups. A $p$ value less than 0.05 was considered statistically significant.

\section{Results}

Between January 1, 2012 and March 31, 2016 we assessed 164 patients with newly or previously diagnosed acromegaly. There were 147 treated and 17 untreated patients. Of the 147 patients assessed after therapy, $137(93.2 \%)$ had pituitary surgery, $116(78.9 \%)$ were on medical treatment at the last evaluation (51 on octreotide LAR, 33 on lanreotide PR or autogel, 15 on pegvisomant, 30 on cabergoline, and 10 were involved in clinical trials with SSA), and $67(45.5 \%)$ had radiotherapy (11 low-voltage radiotherapy, 27 high-voltage radiotherapy, and 36 gamma-knife; seven patients had two different radiotherapies). 


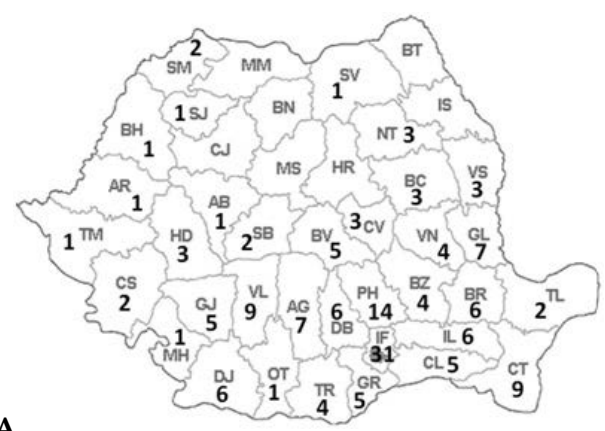

A

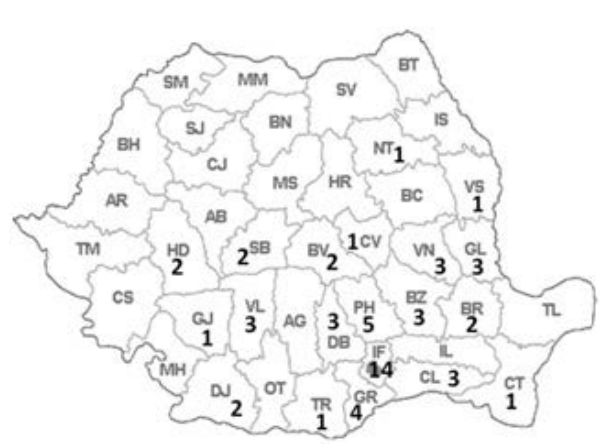

Figure 1. Geographical distribution of the prevalent $\mathbf{( 1 A )}$ and incident $\mathbf{( 1 B )}$ population of acromegalic patients from our centre between January 1, 2012 and March 31, 2016. The numbers represent individual patients from a particular county

Rycina 1. Rozkład geograficzny chorobowości (1A) i zapadalności (1B) w populacji chorych z akromegaliq leczonych w ośrodku autorów w okresie od 1 stycznia 2012 roku do 31 marca 2016 roku. Przedstawiono liczę pacjentów z poszczególnych okręgów

Of the 147 patients assessed after at least one treatment, $71(48.3 \%)$ had a random GH $<1 \mathrm{ng} / \mathrm{mL}, 54$ $(36.7 \%)$ had a normalised age-adjusted IGF-I, and 42 (28.6\%) had both normal random serum GH and IGF-I.

Between January 1, 2012 and March 31, 2016 we diagnosed 57 patients with acromegaly. Of these, 42 were also assessed after at least one treatment. Of the 42 treated patients $20(47.6 \%)$ had a random $\mathrm{GH}<1$ $\mathrm{ng} / \mathrm{mL}, 11(26.2 \%)$ had a normalized age-adjusted IGF-I and $8(19.0 \%)$ had both normal random serum GH and IGF-I. Treatment efficacy for different treatments can be found in Figure 2.

Forty-one patients diagnosed after January 1, 2012 were treated by surgery. Surgery normalised random GH in 10 patients (24.4\%), IGF-I in six patients (14.6\%), and both GH and IGF-I in four patients $(9.7 \%)$. The median random serum $\mathrm{GH}$ was lowered by surgery from $8.7(4.2,22.4) \mathrm{ng} / \mathrm{mL}$ to $2.5(1.2,5.1) \mathrm{ng} / \mathrm{mL}(\mathrm{p}<0.001)$. Serum IGF-I was lowered by surgery from $3.6(3.0,4.2)$ X ULN to 2.6 (1.6, 3.4) X ULN (p < 0,001) (Fig. 3).

Somatostatin analogues were used in 26 patients not cured by surgery. SSA analogues normalised GH in 11 patients (42.3\%), IGF-I in five patients $(19.2 \%)$, and both GH and IGF-I in four patients (15.4\%). In these 26 patients SSA lowered serum random GH from 3.1 $(2.1,5.9) \mathrm{ng} / \mathrm{mL}$ to $1.4(0.8,3.7) \mathrm{g} / \mathrm{mL}(\mathrm{p}=0,009)$. Serum IGF-I was lowered from $3.0(2.5,3.5) X$ ULN to $1.5(1.0$, 2.1) X ULN (p < 0,001) (Fig. 3).

\section{Discussion}

Our study presents the control rate of acromegaly in a sample of 164 patients assessed in a single tertiary centre between January 1, 2012 and March 31, 2016. Also, we present here the control rate and the GH and IGF-I lowering effect of different treatments in patients diagnosed after January 1, 2012. At an estimated prevalence of 60 cases per million and an estimated incidence of 3-4 cases per million [10, 12] per year, this population represents $13.6 \%$ of the total population of acromegalic patients and $16.7-22.3 \%$ of patients with newly diagnosed acromegaly in Romania. To our knowledge, it is the largest study on acromegaly control rate in Romania.

Surgery was the mainstay of acromegaly treatment. In our study, $95.1 \%$ of treated patients had pituitary surgery, a slightly higher figured compared with data from national registries: $89.3 \%$ in Germany [5], 83.8\% in Spain [9], 70.3\% in UK [7], and 68\% in Belgium [6]. Medical treatment for acromegaly came into widespread use in Romania only in the last 5-10 years and is reimbursed only in surgically treated patients, and this could explain the high percentage of surgery. On the other hand, $78.9 \%$ of patients were on medical treatment at the last evaluation (SSA, GH receptor antagonists, dopamine agonists, or clinical trials) as compared with $74.7 \%$ in Spain [9], 60.2\% in UK [7], 58\% in Belgium [6], and $42.6 \%$ in Germany [5]. The high percentage of patients on medical treatment in Romania is probably due to the very low cure rate of surgery (see below). Radiotherapy was used in $45.5 \%$ of patients as compared with $22.2 \%$ in Germany [5], 34\% in Belgium [6], and 44.7\% in UK [7]. In all of these countries the percentage of radiotherapy fell dramatically in recent decades, primary radiotherapy being practically absent. In Romania, of the 67 patients with radiotherapy, only seven $(10.4 \%)$ were diagnosed after 2012, the remaining $60(89.6 \%)$ being diagnosed prior to 2012.

We found an overall disease control rate $(\mathrm{GH}<$ $1 \mathrm{ng} / \mathrm{mL}$ and age-normalised IGF-I) of $28.6 \%$. This would increase to $36.7 \%$ if only an age-normalised IGF-I were considered and to $48.3 \%$ if only random $\mathrm{GH}<1 \mathrm{ng} / \mathrm{mL}$ were used to define disease control. The UK acromegaly Register [7] reported a rate of age-normalised IGF-I of $59 \%$ for patients assessed after 2000 . The rate of $\mathrm{GH}$ and IGF-I control was $49 \%$, but in this register normal GH 


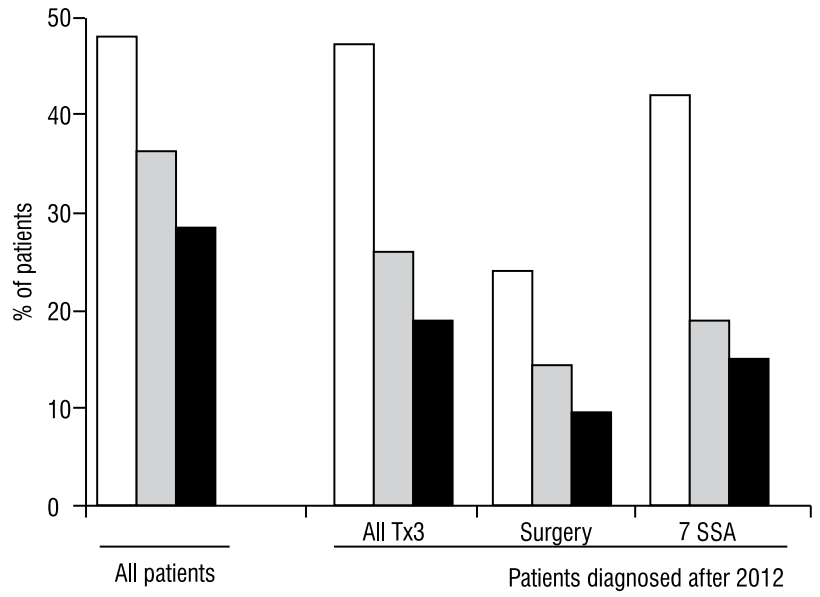

Figure 2. Percentages of patients with normalised random GH (white bars), IGF-I (grey bars), or GH and IGF-I (black bars) in all treated patients $(n=147)$ or patients diagnosed after 2012 (all treatments, $n=42$; surgery, $n=41$; somatostatin analogues, $n=26)$

Rycina 2. Odsetek pacjentów z normalizacją stężeń hormonu wzrostu (growth hormone, GH) (białe stupki), insulinopodobnego czynnika wzrostu 1 (insulin-like growth factor-1, IGF-1) (szare stupki) oraz GH i IGF-1 (czarne stupki) w pomiarach przygodnych $u$ wszystkich leczonych pacjentów $(n=147)$ oraz u pacjentów, u których rozpoznano chorobę po 2012 roku (wszystkie metody leczenia, $n=42$; leczenie chirurgiczne, $n=41$; analogi somatostatyny, $n=26$ )

was defined as $<2 \mathrm{ng} / \mathrm{mL}$. The German Acromegaly Register [5] reported a rate of age-normalised IGF-I of $71.9 \%$, a figure two times higher than in our results; $\mathrm{GH}$ data are not reported. The rate of age-normalised IGF-I was 56\% in AcroBel [6] and 76\% in the Spanish Acromegaly Registry [9]. Overall, the rates of disease control in patients from European national registers are $20-40 \%$ higher than in Romania, probably due to the poor result of surgery (see below) in our country. Also, the pre-treatment GH but not IGF-I levels are known to have an impact on the disease control rate of medical therapy $[8,13]$. However, in the subgroup of patients from our study submitted to somatostatin analogues the pre-treatment GH and IGF-I levels were $3.1 \mathrm{ng} / \mathrm{mL}$ and 3.0 X ULN, lower than in this meta-analysis [13].

In the subgroup of patients diagnosed after 2012 surgery normalised GH, IGF-I, or both GH and IGF-I in $21.9 \%, 14.5 \%$, and $9.7 \%$ of patients, respectively. The rate of normalised age-adjusted IGF-I by surgery alone is over $30 \%$ in national registers [5-7,9]. This low control rate is unexpected because most of the surgical interventions on our patients were carried out in a university tertiary neurosurgical unit with more than 50 pituitary surgeries per year. The number of pituitary surgical interventions is a well-accepted and important factor in surgical success [14-16]. However, although active

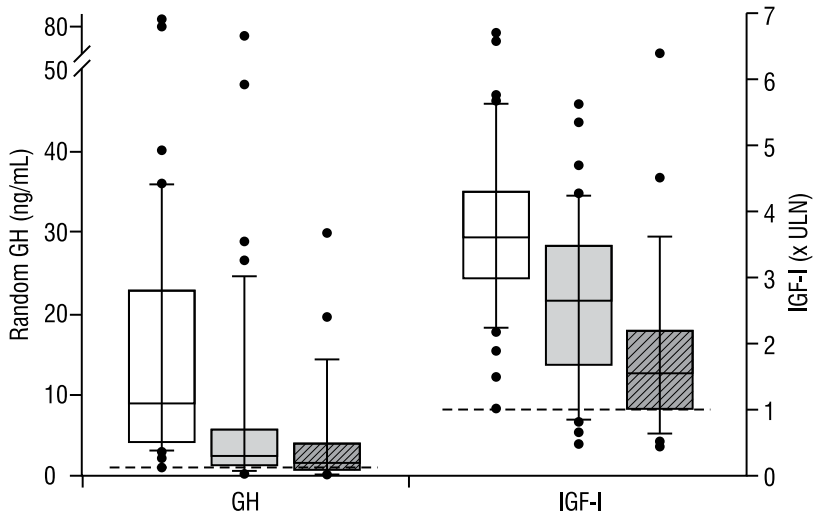

Figure 3. Effect of surgery ( $n=41$, grey bars) and somatostatin analogues $(n=26$, shaded bars) compared with baseline $(n=$ 41, white bars) on random serum GH (left Oy axis) and IGF-I (right Oy axis)

Rycina 3. Zmiana stężenia w surowicy hormonu wzrostu (growth hormone, GH) (lewa strona osi Y) i insulinopodobnego czynnika wzrostu 1 (insulin-like growth factor-1, IGF-1 (prawa strona osi Y) w pomiarach przygodnych pod wptywem leczenia chirurgicznego ( $n=41$, szare stupki) oraz terapii analogami somatostatyny ( $n$ $=26$, zakreskowane stupki) $w$ stosunku do stanu wyjściowego ( $n=41$, biate stupki)

postsurgical disease was the most frequent scenario, median random GH and IGF-I serum levels were significantly lowered by pituitary surgery.

Somatostatin analogues seemed to have a lower efficacy in our population compared with published national registers [5-7]. However, not all patients were on maximal doses of SSA. Also, the number of the patients in the subgroup diagnosed after year 2000 is too small $(n=26)$ to draw firm conclusions. As for surgery, SSA were able to significantly lower random GH and IGF-I serum levels.

Although our sample population represents $13.6 \%$ of the total population of acromegalic patients in Romania and covers most of its territory, the main limitation of our study is the absence of a real registry for acromegaly. In the European countries where a nationwide registry is functional [5-7,9] it includes most of the acromegalic population and many practicing offices, from university centres to smaller regional hospitals. However, there are countries where acromegaly treatment is restricted to university centres [10]. Unfortunately, in our study, the practicing bias of a single centre cannot be ruled out. Also, there are 15 patients who were diagnosed after 2012, who were not reassessed after any kind of treatment. It is possible that some of these patients were cured by surgery and never returned to our centre, thus artificially lowering the cure rate.

To our knowledge it is the largest study on acromegaly control rate in Romania. Also, our study showed consistency in patient assessment because we used the same assays 
for ultrasensitive GH and IGF-I measurement during the whole period of the study, as recommended by the last acromegaly guidelines [11]. Moreover, we defined acromegaly control based on the latest guidelines by using random $\mathrm{GH}$ instead of mean 24-h GH or minimum GH during an oral glucose tolerance test (OGTT) and age-normalised IGF-I [11]. There is a study on a larger population of 336 acromegalic patients in Romania [17] containing also data on cure rate. However, it focused on mortality, used different criteria for acromegaly control definition, and GH was measured using an immunoradiometric assay. Unfortunately, also national registries from European countries use slightly different criteria for defining disease control. For example, the German Acromegaly Register [5] does not use GHlevels (random, mean, or minimum during OGTT), and the UK Acromegaly Register uses a random GH cut-off value of 2 $\mathrm{ng} / \mathrm{mL}$ for the definition of acromegaly control [7].

\section{Conclusions}

In conclusion, in Romania acromegaly benefits from the whole spectrum of therapeutic interventions: pituitary surgery in high-volume centres, long-acting somatostatin analogues, GH receptor antagonist, and modern radiotherapy. However, the control rate remains disappointing.

\section{References}

1. Sherlock M, Ayuk J, Tomlinson JW, et al. Mortality in patients with pituitary disease. Endocr Rev. 2010; 31(3): 301-342, doi: 10.1210/er.2009-0033 indexed in Pubmed: 20086217.

2. Melmed S, Colao A, Barkan A, et al. Acromegaly Consensus Group. Guidelines for acromegaly management: an update. J Clin Endocrino Metab. 2009; 94(5): 1509-1517, doi: 10.1210/jc.2008-2421, indexed in Pubmed: 19208732.

3. Murray RD, Melmed S. A critical analysis of clinically available somatostatin analog formulations for therapy of acromegaly. J Clin Endocrinol Metab. 2008; 93(8): 2957-2968, doi: 10.1210/jc.2008-0027, indexed in Pubmed: 18477663.
4. Tritos NA, Biller BMK. Pegvisomant: a growth hormone receptor antagonist used in the treatment of acromegaly. Pituitary. 2017 20(1): 129-135, doi: 10.1007/s11102-016-0753-y, indexed in Pubmed 27631335 .

5. Schöfl C, Franz H, Grussendorf M, et al. participants of the German Acromegaly Register. Long-term outcome in patients with acromegaly: analysis of 1344 patients from the German Acromegaly Register. Eur Endocrinol. 2013; 168(1): 39-47, doi: 10.1530/EJE-12-0602, indexed in Pubmed: 23087126.

6. Bex M, Abs R, T'Sjoen G, et al. AcroBel--the Belgian registry on acromegaly: a survey of the 'real-life' outcome in 418 acromegalic subjects. Eur J Endocrinol. 2007; 157(4): 399-409, doi: 10.1530/EJE-07-0358, indexed in Pubmed: 17893253

7. Howlett TA, Willis D, Walker G, et al. UK Acromegaly Register Study Group (UKAR-3). Control of growth hormone and IGF1 in patients with acromegaly in the UK: responses to medical treatment with somatostatin analogues and dopamine agonists. Clin Endocrinol (Oxf). 2013; 79(5): 689-699, doi: 10.1111/cen.12207, indexed in Pubmed: 23574573.

8. Gheorghiu ML, Găloiu S, Vintilă M, et al. Beneficial effect of dose escalation and surgical debulking in patients with acromegaly treated with somatostatin analogs in a Romanian tertiary care center. Hormones (Athens). 2016; 15(2): 224-234, doi: 10.14310/horm.2002.1675, indexed in Pubmed: 27376425.

9. Sesmilo G, Gaztambide S, Venegas E, et al. REA investigators. Changes in acromegaly treatment over four decades in Spain: analysis of the Spanish Acromegaly Registry (REA). Pituitary. 2013; 16(1): 115-121, doi 10.1007/s11102-012-0384-x, indexed in Pubmed: 22481632.

10. Kauppinen-Mäkelin R, Sane T, Reunanen A, et al. A nationwide survey of mortality in acromegaly. J Clin Endocrinol Metab. 2005; 90(7): 4081-4086, doi: 10.1210/jc.2004-1381, indexed in Pubmed: 15886256.

11. Katznelson L, Laws ER, Melmed S, et al. Endocrine Society. Acromegaly: an endocrine society clinical practice guideline. J Clin Endocrinol Metab. 2014; 99(11): 3933-3951, doi: 10.1210/jc.2014-2700, indexed in Pubmed: 25356808 .

12. Holdaway IM, Rajasoorya C. Epidemiology of acromegaly. Pituitary. 1999; 2(1): 29-41, indexed in Pubmed: 11081170.

13. Freda PU, Katznelson L, van der Lely AJ, et al. Long-acting somatostatin analog therapy of acromegaly: a meta-analysis. J Clin Endocrino Metab. 2005; 90(8): 4465-4473, doi: 10.1210/jc.2005-0260, indexed in Pubmed: 15886238.

14. Laws ER. Surgery for acromegaly: evolution of the techniques and outcomes. Rev Endocr Metab Disord. 2008; 9(1): 67-70, doi: 10.1007 s11154-007-9064-y, indexed in Pubmed: 18228147.

15. Bates PR, Carson MN, Trainer PJ, et al. UK National Acromegaly Register Study Group (UKAR-2). Wide variation in surgical outcomes for acromegaly in the UK. Clin Endocrinol (Oxf). 2008; 68(1): 136-142, doi: 10.1111/j.1365-2265.2007.03012.x, indexed in Pubmed: 17803712.

16. Erturk E, Tuncel E, Kiyici S, et al. Outcome of surgery for acromegaly performed by different surgeons: importance of surgical experience. Pituitary. 2005; 8(2): 93-97, doi: 10.1007/s11102-005-3280-9, indexed in Pubmed: 16195777.

17. Galoiu S. Mortality of Patients with Acromegaly FROM a Tertiary National Neuroendocrine Center. Acta Endocrinologica (Bucharest). 2015 11(4): 476-481, doi: 10.4183/aeb.2015.476. 